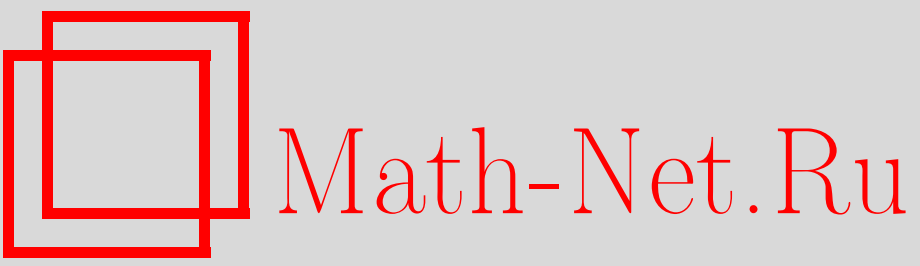

С. М. Никольский, А. С. Поспелов, С. А. Теляковский, П. Л. Ульянов, С. В. Умняшкин, Ю. А. Чаплыгин, Александр Васильевич Ефимов (некролог), УМН, 2002, том 57, выпуск 3, 135-136

DOI: https://doi.org/10.4213/rm438

Использование Общероссийского математического портала Math-Net.Ru подразумевает, что вы прочитали и согласны с пользовательским соглашением

http: //www.mathnet.ru/rus/agreement

Параметры загрузки:

IP : 54.198 .55 .26

26 апреля 2023 г., 03:52:50 


\section{АЛЕКСАНДР ВАСИЛЬЕВИЧ ЕФИМОВ}

5 ноября 2001 г. скончался крупньй специалист по математическому анализу и его приложениям заслуженный деятель науки Российской Федерации доктор физико-математических наук профессор Александр Васильевич Ефимов.

А. В. Ефимов родился 10 ноября 1924 г. в селе Наумово Бурурлинского района Нижегородской области. В 1941 г., окончив 8 классов средней школы, пошел слесарем на Горьковский автозавод. В ноябре 1942 г. был призван в ряды Красной Армии. Воевал рядовьп, затем командиром стрелкового отделения, участвовал в боях Северо-Западного и 2-го Прибалтийского фронтов, награжден медалью "За отвагу". В июле 1944 г. после тяжелого ранения был демобилизован в звании старшего сержанта. После демобилизации вернулся в Горький, работал на заводах, окончил вечернюю школу.

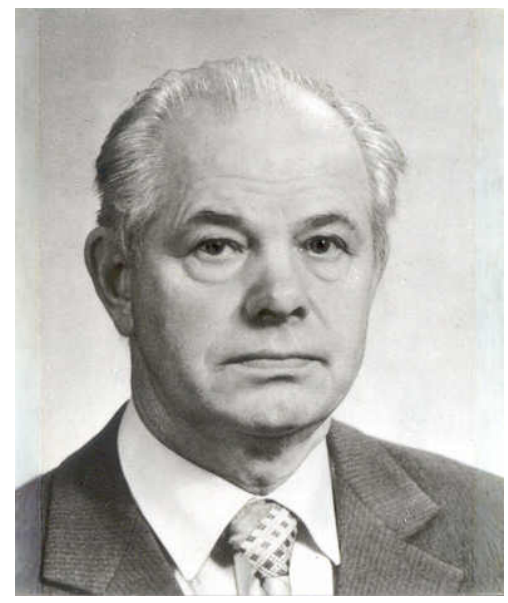

В 1946 г. Александр Васильевич поступил на физико-математический факультет Горьковского университета, который окончил в 1951 году. С этого времени вся его жизнь была посвящена научно-педагогической деятельности. Он работал учителем в средней школе, преподавал в Горьковском политехническом институте, Кемеровском горном институте, Краснознаменной военно-воздушной академии (г. Монино), Московском лесотехническом институте.

Начиная с момента организации в 1967 г. Московского государственного института электронной техники, А. В. Ефимов работал в этом институте. Под его руководством создавалась каффедра высшей математики, разрабатывались математические курсы, опирающиеся на современные достижения вычислительной техники, формировалась система фундаментальной математической подготовки инженеров микроэлектроники. Эта деятельность нашла отражение в двухтомном учебном пособии А. В. Ефимова по математическому анализу, изданном в 1980 году.

Значительную роль в преподавании математики в вузах Советского Союза и России играет "Сборник задач по математике для втузов" в 4-х томах, выходящий под редакцией А.В.Ефимова, участвовавшего также в составе авторского коллектива. Этот сборник начал издаваться в 1981 г. и к концу 80-х гг. выдержал 3 издания, переведен на английский, испанский и французский язьки. Сборник получил высокую оценку преподавателей и завоевал широкую популярность.

В последние месяцы своей жизни Александр Васильевич много работал над подготовкой 4-го издания сборника, первьй том которого вышел в свет в конце 2001 года.

Из научных достижений А.В. Ефимова отметим большой цикл его исследований, продолжающий работы А. Н. Колмогорова и С. М. Никольского по изучению асимптотического поведения верхних граней уклонений сумм Фурье на классах функций.

Кандидатскую диссертацию, выполненную под руководством С.Б. Стечкина в аспирантуре Математического института им. В.А. Стеклова Академии наук СССР, А. В. Ефимов защитил в 1957 году. Докторскую диссертацию - в 1963 году. 
Являясь заведующим одной из основных кафедр вновь созданного института МИЭТ, Александр Васильевич отчетливо понимал, что подготовка специалистов в такой наукоемкой и бурно развивающейся отрасли, как микроэлектроника, невозможна без привлечения студентов к научным исследованиям. Будучи крупным специалистом по теории аппроксимации, А. В. Ефимов видел роль этой теории в приложениях к задачам цифровой обработки информации, оптимизации каналов связи, разработке специализированных вычислительных микропроцессорных устройств и систем.

Под руководством А. В. Ефимова и при его личном участии на кафедре высшей математики МИЭТ сформировалась школа по математическим исследованиям в области цифровой обработки информации - сигналов и изображений. Им, а также под его руководством его учениками, был получен ряд существенных результатов, используемых при разработке специализированных микропроцессорных устройств, реализующих быстрые алгоритмы обработки сигналов. Эти результаты нашли отражение в монографии Б. И. Голубова, А. В. Ефимова и В. А. Скворцова "Ряды и преобразования Уолша. Теория и применение", изданной в 1987 г., и в обзорной статье А.В. Ефимова, А.С. Поспелова и С.В. Умняшкина "Некоторые свойства мультипликативных ортонормированных систем, используемые в цифровой обработке сигналов" (Труды МИРАН, 1997, т. 219, с. 137-182), а также в 7 кандидатских диссертациях, выполненных под его руководством, и двух докторских диссертациях его учеников.

А. В. Ефимов всей своей предыдущей научной деятельностью был хорошо подготовлен к тому, чтобы возглавить прикладные исследования в указанном направлении. Полученные им результаты по теории приближения функций, суммированию тригонометрических рядов, изучению свойств мультипликативных систем послужили тем фундаментом, на которьй опирались в дальнейшем прикладные исследования его самого и его учеников.

Александр Васильевич Ефимов являлся автором более 100 публикаций, создателем значительной школы молодых исследователей. Под его руководством было подготовлено 28 кандидатских диссертаций, трое его учеников стали докторами наук.

Разнообразие творческих интересов А. В. Ефимова проявилось в его активном участии в организации математического образования в вузах СССР и России. Будучи прекрасным лектором, он отлично понимал необходимость фундаментального математического образования инженеров, всегда и везде отстаивал и пропагандировал такой подход. Более 20 лет он участвовал в работе Научно-методического совета по математике Министерства образования, являлся руководителем секции технических средств обучения и использования ЭВМ, многие годы был заместителем председателя этого совета. Им была проделана болшая работа по совершенствованию методики преподавания математических курсов, внедрению ЭВМ в учебньй процесс, органичному включению численных методов в практику изучения математики студентами инженерных специальностей.

В общении с людьми Александра Василевича отличали исключительная доброжелательность, доброта и отзьвчивость, что не мешало его принципиальности и требовательности. Ему было чуждо какое-либо высокомерие.

Светлая память об Александре Василевиче Ефимове навсегда останется в сердцах всех, кто его знал.

C. М. Никольский, А. С. Поспелов, С. А. Теляковский, П. Л. Ульянов, С. В. Умняшкин, Ю. А. Чапльъин 